\title{
Accessible Accommodation: Do Resorts in Egypt Provide Services and Facilities Required for Guests with Disabilities?
}

\author{
Khlloud Abd-EIraof \\ Hotel Management Department, \\ Minia University.
}

Abd-Elbary Ahmed Dawood

Professor of Hotel Management Department, Minia University.

\section{Abuelkassem Mohammad} \\ Lecturer at Hotel Management Department, \\ Faculty of Tourism and hotels, Minia University
}

\begin{abstract}
Accommodation is a serious challenge for persons with disabilities (PWD) that determine destination selection. When a disabled guest cannot find suitable accommodation that meets his/her needs, he/she will change his/her destination choice. This is because PWDs need easy access to enjoy their tourism experience in equality and usability standards. This research aimed to explore and evaluate disabled services and facilities provided for persons with disabilities in resorts in Egypt. A quantitative approach was adopted in this study and a questionnaire survey was used to collect primary data. A total of 106 questionnaire forms were conducted among resorts managers. The sample included resorts hotels (three, four and five-star) from major tourist cities in Egypt, including Cairo; Ain- Sukhna; Aswan; Luxor; Hurghada; Sharm ElSheikh. Descriptive statistics and One-way ANOVA test were used to analyze obtained data. The study revealed that a significant percentages of the approached resorted had provided varied services and facilities for PWD which have resulted in some advantages, such as: improving resort image and enhancing customer satisfaction. The study also showed that there were some challenges that faced investigated resorts of providing services and facilities, limited number of disabled guests. The study added that there are some reasons for decrease in PWD numbers in Egyptian resorts, such as high costs associated with providing disabled facilities. The study provided valuable recommendations to enhance services and facilities for persons with disabilities in resorts.
\end{abstract}

Keywords: Services and Facilities, Persons with Disabilities (PWD), Resorts, Egypt.

\section{Introduction}

According to European Network for Accessible Tourism (ENAT) (2015) many administrators in tourism sector are still unaware of the potential of the accessible market and how to meet the needs of tourists with disabilities. European Commission (2017) declared that travelling for PWD can be a real challenge. However, through making basic adjustments to a facility, providing accurate information and understanding the needs of PWD; a hotel can increase visitor number of PWD. Improving the accessibility of tourism services increases quality and the enjoyment of all tourists; it also improves the quality of life in local communities. ENAT (2015) stated that there should be a commitment and cooperation between tourism authorities, destinations and enterprises to provide an excellent service to PWD. 
Chen (2005) and Poria, et al. (2011) noted that the economic potential of the disabled market which characterized by strong loyalty. It is estimated that PWD segment is a potential market of one million individuals in USA. This group with disabilities is expected to double by the year 2030. It is now widely recognized that PWD along their assistants, family, and friends constitute a large potential consumer market segment. According to Poria, et al. (2011) a number of studies focused on PWD considering either on demographic or socioeconomic characteristics, with just a few studies exploring employees with disabilities, overlooking guests with disabilities. In Egypt, there is a limited studies regarding accessible accommodation that provide access services and facilities to disabled guests .So, this research represents an exploratory study that aims to explore and evaluate disabled services and facilities provided for persons with disabilities in resorts in Egypt.

\section{Literature Review}

\subsection{Persons with Disabilities}

According to the World Bank $(2002,10)$ a disabled person is defined as "any person unable to ensure by himself or herself a normal life, as a result of deficiency in his or her physical or mental capabilities". Disabled persons include those who have long-term physical, mental, intellectual or sensory impairments which in interaction with various barriers may hinder their full and effective participation in society on an equal basis with others (United States Agency for International Development USAID, 2011). Ministry of Statistics and Programs Implementation in India (MOSPI) (2011) declared that PWD is a person with limitations or absence of ability to perform the human activities. In Egyptian legislation, disabled person is defined as everyone has a total malfunction or partial physical, intellectual or sensory whenever a longterm stable can prevent him from participating fully and effectively with the community on an equal basis with others (Hagrass, 2005). Poria, et al., (2011) and Popiel (2014) explained that disability can be characterized by three main measures as follow:

Physical accessibility: this applies to people with physical disability, frequently requiring the use of wheelchairs or walking aids and often demanding other conveniences, such as: railings, ramps and lifts.

Sensory accessibility: this applies to people with impaired sight or hearing (Auditory Disabilities) or other similar impairments. Such people require special services such as tactile signs, visual signs, labels, audio-visual systems, warning sounds for lifts and crossings, etc.

Communication accessibility: which applies to people with communication impairments such as people having difficulties of read, write, hear or speak as well as people coming from different cultural backgrounds who require some explanation or additional information.

The World Health Organization (2011), in its world report on disability summary, estimated that there is more than one billion (1000 million) people in the world live with some form of disability. This constitutes about $15 \%$ of the world's population (World Tourism Organization and Fundación ACS, 2015). 
There are about 650 million people with disabilities in the Middle East, which represent a significant potential market for tourism industry (Popiel, 2014). Darcy and Pegg (2010) noted that during the last decade, PWD made an economic contribution of tourism in Europe, USA, Canada and Australia.

\subsection{Disabled Services and Facilities in the Hospitality industry}

\subsubsection{Disabled Services in Resorts}

Bacon and Richard $(2011,3)$ defined a resort as "a place frequented by people for recreation and relaxation" or "a compound of buildings and facilities located in a scenic area, providing lodgings, entertainment, and a relaxing environment to people on vacation". Brun (2010) added that resorts provide many services, including: rooms; suites; public dinning; banquet; lounges and entertainment facilities, as well a resort in general prepare and serve food and beverages. Traditional resorts provide rooms, banquets and restaurants. Additional resorts get profits from telephone call services, laundry, travel services, internet and recreational, entertainment activities. Ali (2008) stated that resorts provide cleaning and maintaining to the property, moreover heat and light and power. The European Disability Forum (2001) explained that by improving the quality of service for disabled people, the quality of services to those tourists without disability could also be improved.

Breedt (2007) noted that enjoying in destinations is very limited because the lack of facilities provided for travelers with disabilities in Africa and the main reason of this lack of services and facilities and the failure of countries governments and tourism administrations to make transportation and accommodation accessible within these countries. Powell (1995), Bloemer, et al. (1998), Ali (2008) and Shahin (2010) noted that quality in service is very important especially for the growth and development of service sector business enterprises. It works as an antecedent of customer satisfaction. According to Nestoroska (2014) the staff must be trained and qualified to recognize and satisfy needs and wants of guests. Peniston (1996) and Russell (1996) noted that training programs can help hotel employees (managers and staff) to understand how to best deal, serve and communicate with PWD.

\subsubsection{Disabled Facilities in Resorts}

Disabled facilities include the main elements in the architectural design, necessary furniture and equipment required for accessible accommodation for PWD, as discussed in the subsequent paragraphs.

\section{Fixture}

The first facility of the fixture is parking space for PWD which is an unobstructed rectangular area exclusive of any lane or path for the temporary parking of a car or vehicle (City of Mississauga, 2015). According to ADA Design Standards (2010), designating accessible parking is considered to be a top priority as it enables PWD to get in the door. Accessible parking spaces should be declared by International Symbol of Accessibility signs. The second element of architectural design is accessible route, Standards New Zealand (2001) and United States Access Board (2002) defined the accessible route as a route that is used by PWD. In other words, it is a permanent route that used by a wheelchair user, walking device or by a person with a guide dog. 
Accessible ramp is another important element of fixture. Standards New Zealand (2001) and United Nations (2003) classified the accessible ramps to straight, zigzag and L-shaped. Curved or circular ramp are not required in an accessible route; the minimum width of a ramp should be $91.5 \mathrm{~cm}$, exclusive of flared sides. According to City of Mississauga (2015) landings should have a minimum size not less than $244 \times 244 \mathrm{~cm}$ if located at the top or bottom of a ramp. Ramp and landing surfaces should be firm, stable, and slip-resistant. Standards New Zealand (2001), United States Access Board (2002) and City of Mississauga (2015) agreed that ramps should be equipped with handrails which are on both sides. It is provide a support to ensure a safe and stable walk before ascending or descending the ramp. The clear width between handrails should be $91.5 \mathrm{~cm}$ minimum. Another common element is accessible corridors. according to Standards New Zealand (2001) all corridors on accessible routes within a building shall have a minimum width of $150 \mathrm{~cm}$, this width allows space for using by PWD and the aids they require such as a wheelchair, for a blind or aged person to walk side by side, or for a blind person and guide dog to use. This width is also essential to allow a wheelchair to make a $90^{\circ}$ turn into a doorway in one movement. Accessible entrance is also an essential piece of fixture for PWD. United States Access Board (2002) and City of Toronto (2004) declared that the accessible entrance to a facility should have a level threshold or an approach through ramp with an appropriate slope. A level approach space is $120 \mathrm{~cm} \times 120 \mathrm{~cm}$ both inside and outside the entrance door. The entrance way should lighted up to be clearly recognizable from the surroundings.

Standards New Zealand (2001) declared that accessible doors should be designed to permit operation by one person in a single motion with little effort. Power-operated doors are the best for PWD. ADA (2010) noted that the activator system should be automatic or placed within easy reach. Another main architecture design includes information, reception and service counter. According to City of Mississauga (2015) information, reception and service counters should be accessible, a choice of counter heights is recommended to provide a range of options for many persons. Lowered sections will serve children, short persons and PWD using mobility devices, such as a wheelchair or scooter. The choice of heights should also extend to speaking ports and writing surfaces. City of Toronto (2003) added that providing a free space of knee under the counters for PWD who using a wheelchair or scooters is very important and these counters must be identified by signage. United Nations (2003), City of Toronto (2004) and City of Mississauga (2015) agreed that the suitable design of toilet facilities (public toilets and in-room toilets) should enable the usability and safety for PWD. United Nations (2003) noted that accessible elevator should serve all floors used by the public. The minimum internal elevator dimensions, appropriate for one PWD with wheelchair, are $1.00 \mathrm{~m} \times 1.30 \mathrm{~m}$. Its door should not be less than $80 \mathrm{~cm}$. The inside of the elevator should have a handrail on three sides mounted at $80 \mathrm{~cm}$ to $85 \mathrm{~cm}$ from the floor. 
For easy access, the control panel should be located $90 \mathrm{~cm}$ to $1.20 \mathrm{~m}$ from the floor. Control buttons should be in an accessible location, lighted up and their diameter should be no smaller than $0.2 \mathrm{~cm}$. The main and critical area is accessible guest room. Greater London Authority (2010) stated that accessible room is used in preference to wheelchair accessible rooms. It is a room that has adequate circulation space for a wheelchair and is designed to facilitate use by PWD; but it can also be used by all other potential guests. According to United States Access Board (2004), Ministry of Tourism in Egypt (2010) and ADA (2010) about $1 \%$ of the total rooms in a hotel with a minimum of 1 room should be accessible rooms. If accessible room is not on the ground floor an elevator must be provided. The room door should be at least $1 \mathrm{~m}$ wide. Door handles should be between $90-120 \mathrm{~cm}$ from floor level, safety chain and spyholes in bedroom doors should be positioned "between" $110-120 \mathrm{~cm}$ from floor level. Floor should be of hard surface without carpet.

According to City of Toronto (2004) cafeterias, restaurants, cafés, bars, and other areas that providing food and beverage services, should be accessible to PWD. Aisle spaces between furniture, equipment should be wide enough to allow a person using mobility aids to pass (United States Access Board, 2004). United States Access Board (2004) declared that meeting rooms and conferences and theaters (assembly areas) should all be designed to be accessible to PWD, including persons using mobility aids and persons with sensory limitations. Standards New Zealand (2001) stated that recreational facilities providing programs and services to the public or to special groups, and clubs, should be fully accessible to PWD. All areas and amenities should be accessible to persons using mobility aids, persons with visual impairments and persons with hearing impairments.

Indoor swimming pools and related amenities should all be accessible to PWD. All pool area floor surfaces should be easy to clean, non-glare, non-slip and finished with a light color. Signage in pools should be suitable for persons with low vision (United States Access Board, 2002). According to City of Mississauga (2015) emergency exits must include the same accessibility features. The doors and routes must also be marked in a way that is accessible to all individuals, including those who may have difficulty with literacy, such as children or persons speaking a different language. City of Toronto (2004) indicated that persons who use a guide dog require access to an area for their service animal to relieve themselves. Such service animal relief areas need to be in an accessible location, feature good drainage and provide a garbage can for waste disposal.

\section{Furniture}

United States Access Board (2004), Ministry of Tourism in Egypt (2010) and ADA (2010) agreed that accessible room furniture must have the following standards; clothes rail to be mounted at maximum height of $1.40 \mathrm{~m}$, tables or desks with clear under space should be at least $65 \mathrm{~cm}$ high and $75 \mathrm{~cm}$ wide, mirrors at seating level with a bottom edge no higher than $90 \mathrm{~cm}$ above floor, firm bed surface should be "between" $45-54 \mathrm{~cm}$ heights and at least one chair seat with rigid arms should be available. 
According to City of Toronto (2004) cafeterias, restaurants, cafés, bars, and other areas that providing food and beverage services, should be accessible to PWD. Accessible seating locations in restaurants for persons using mobility aids should be available in all areas or levels to provide food or beverage services. Aisle spaces between furniture, equipment should be wide enough to allow a person using mobility aids to pass; these aisles should be a minimum of $106 \mathrm{~cm}$ wide. Where counter service is provided, at least one section of the counter should be no higher than $91.5 \mathrm{~cm}$ by $76 \mathrm{~cm}$ wide, to allow a person using a wheelchair or scooter to approach. Where cafeteria or buffet style food services are provided, displays should be accessible and mounted on surfaces no higher than $91.5 \mathrm{~cm}$ from the floor.

Overhead display shelves should be no higher than $122 \mathrm{~cm}$. Where tray rails are provided, they should be as continuous as possible to allow persons using wheelchairs or scooters to slide a tray along easily (ADA, 2010).

United States Access Board (2004) added that accessible seating in meeting rooms and conferences and theaters (assembly areas) should be distributed and integrated throughout seating areas of assembly rooms with different positions available to all PWD. Standards New Zealand (2001) stated that recreational facilities providing programs and services should be fully accessible to PWD. All entertainment and assembly areas should be able to serve persons using various mobility aids and persons who have visual impairments (United States Access Board, 2004).

\section{Equipment}

City of Toronto (2003) noted that providing assistive speaking devices in reception area is important for PWD who may have difficulty with hearing thus affecting production of normal audible levels of sound, using of contrast colors, tactile difference or audio landmarks such as receptionist voice or music source can assist PWD with vision loss or no vision to locate service counters or speaking ports. United Nations (2003) discussed that for easy access in elevators, the control panel should be located $90 \mathrm{~cm}$ to $1.20 \mathrm{~m}$ from the floor. Control buttons should be in an accessible location and lighted up; their diameter should be no smaller than $0.2 \mathrm{~cm}$, the numbers on the floor selector buttons should be embossed to be easily recognizable by touch. Tactile numbers should be located in both sides of the door jambs at an approximate height of $1.50 \mathrm{~m}$ to help person with visual impairment to identify the floor reached. Re-opening activators should be provided; the door opening period should be no less than five seconds. Audiovisual signals should be provided; in another meaning the elevator should signal arrival at each floor by means of a bell and a light to alert person with visual impairment and hearing-impaired person's together surface (ADA, 2010 and City of Mississauga, 2015).

According to United States Access Board (2004) main room lights should be controllable from the bed. Electrical equipment e.g. TV and air condition should have remote control. Telephone should have larger buttons and a button to summon assistance in an emergency. According to City of Mississauga (2015) persons with visual impairments will need a means of quickly locating exits - audio or talking signs could assist. 
In the event of fire when elevators cannot be used, areas of rescue assistance are an asset to anyone who would have difficulty traversing sets of stairs. Where emergency warning systems are provided, they shall include both audible alarms and visible alarms. United Nations (2003) noted that all toilets should be equipped with an alarm system.

\section{Research Methodology}

A quantitative approach was adopted in this research. Primary data collection involved using a questionnaire survey that was distributed among resorts managers. The questionnaire was divided into four main parts. Part one was about resort profile (resort region, resort name, tourist grade) in addition to one question about providing services and facilities for PWD, the scale that used for this section was yes/no question $(n=106)$. Part two was directed to resorts that provide services and facilities for PWD to explore such services and facilities $(n=84)$ this number has been revealed in Table (2) at results and discussion section; the authors used a three point Likert Scale, dichotomous questions and contingency questions. Part three was dedicated to resorts that did not provide services and facilities for PWD to determine the obstacles of providing such services and facilities in resorts $(n=22)$, the authors used a three point Likert Scale and dichotomous questions. Part four was about additional comments or suggestion that could help improving services and facilities of PWD ( $n=106)$, the authors used open-ended question. The questionnaire was validated by using peer review technique through discussing and reviewing research method with many peers in the same field. In addition, the questionnaire form was reviewed by a statistics specialist to guarantee its validity.

The population of this study includes resort hotels in Egypt. It can estimated that the number of the resorts were about 420 resorts; based on major tour operators websites, Egyptian Hotel Guide (2016 edition) and personnel communication with governmental officials in the Ministry of tourism. Mainly the common areas of resorts in Egypt are coastal cities, such as Red Sea province and South Sinai province, in addition to some few resorts in other cities including: Cairo; Luxor; Aswan. A random sampling technique was adopted using computer software. The sample comprises 106 resorts was selected and represented about $25 \%$ of the research population (See table 1). A total of 106 questionnaire forms were distributed and self-administered among resorts managers to explore disabled services and facilities in resorts.

Table (1): Research sample according to resorts regions and tourist grade

\begin{tabular}{|lccccc|}
\hline Region & 5 star & 4 star & 3 star & Total & Percent \\
\hline Hurghada & 22 & 19 & 6 & 47 & $44.3 \%$ \\
\hline $\begin{array}{l}\text { Sharm El- } \\
\text { Sheikh }\end{array}$ & 19 & 14 & 6 & 39 & $36.8 \%$ \\
\hline Ain Sukhna & 4 & 2 & 1 & 7 & $6.6 \%$ \\
\hline Cairo & 5 & - & - & 5 & $4.7 \%$ \\
\hline Luxor & 5 & - & - & 5 & $4.7 \%$ \\
\hline Aswan & 2 & 1 & - & 3 & $2.8 \%$ \\
\hline Total & 56 & 37 & 13 & 106 & $100 \%$ \\
\hline Percent & $51.9 \%$ & $35.8 \%$ & $12.3 \%$ & $100 \%$ & -- \\
\hline
\end{tabular}


Data analysis was performed using Statistical Package for Social Sciences (SPSS) version 16.1 to generate particular data including descriptive statistics and One-way ANOVA Analysis test. The reliability of the questionnaire was ensured through using Cronbache's Alpha test (score of 0.761).

\section{Results and discussion}

\subsection{Providing services and facilities for PWD}

The aim of this question was to identify if the resort provided services and facilities for persons with disabilities or not. The results (Table 2) showed that 84 resorts (79.2\%) were providing services and facilities for PWD and only 22 resorts $(20.8 \%)$ did not provide services and facilities for PWD.

Table (2): Providing services and facilities for persons with disabilities in resort.

\begin{tabular}{|llcc|}
\hline \multicolumn{1}{|c}{ Response } & \multicolumn{1}{c}{ Resorts grades } & Frequency & Percent \\
\hline Yes & 3 star resorts & 3 & $2.8 \%$ \\
\cline { 2 - 4 } & 4 star resorts & 27 & $25.5 \%$ \\
\cline { 2 - 5 } & 5 star resorts & 54 & $50.9 \%$ \\
\cline { 2 - 5 } & Subtotal & $\mathbf{8 4}$ & $\mathbf{7 9 . 2 \%}$ \\
\hline No & 3 star resorts & 10 & $9.4 \%$ \\
\cline { 2 - 5 } & 4 star resorts & 1 & $10.4 \%$ \\
\cline { 2 - 4 } & 5 star resorts & $\mathbf{2 2}$ & $\mathbf{2 0 . 8 \%}$ \\
\cline { 2 - 3 } & $\mathbf{1 0 6}$ & $\mathbf{1 0 0 \%}$ \\
\hline Total & & & \\
\hline
\end{tabular}

Hotel managers were asked about the percentage of PWD form their overall guests. The results (Table 3) showed that the percent of guests with disabilities was less than $25 \%$ from all guests in $98.8 \%$ of investigated resorts. There were only $1.2 \%$ of resorts had guests with disabilities from 25 to $50 \%$ of all its guests.

Table (3): The percent of guests with disabilities from total guests in the resort $(n=84)$.

\begin{tabular}{|lcc|}
\hline Response & Frequency & Percent \\
\hline Less than 25\% & 83 & $98.8 \%$ \\
\hline From 25 to 50\% & 1 & $1.2 \%$ \\
\hline More than 50\% & $\mathbf{0}$ & $\mathbf{0}$ \\
\hline Total & $\mathbf{8 4}$ & $\mathbf{1 0 0 \%}$ \\
\hline
\end{tabular}

\subsection{Services and facilities provided for PWD in resorts}

The purpose of this question was to explore services and facilities provided for persons with disabilities in the resort. In this question the managers can be select more than one response. As shown in Table 6, there were seven services and facilities required improvements in the investigated resorts. The first variable was trained staff to deal with guests with disabilities with a mean score of 2.95 and significant variance of standard deviation (2.3). The second variable was special toilets in rooms of guests with disabilities (mean score 2.94) and there was insignificant variance of standard deviation (0.24). The third variable was accessible rooms for guests with disabilities, recording a mean score of 2.93 and in significant variance of standard deviation (0.26). 
The fourth variable was special equipment for guests with disabilities such as wheelchairs with a score mean of 2.93 and standard deviation of 0.34 . The fifth variable was public toilets for guests with disabilities and recorded a mean score of 2.14 with significant variance of standard deviation (0.97). The sixth variable was reception and reservation area for guests with disabilities (mean was 2.09) and there was no significant variance of standard deviation (0.98). The seventh variable was accessible elevators for guests with disabilities with a score mean of 2.00 and standard deviation was 0.97 . Two variables were completely unavailable, the first one was corridors for guests with disabilities (mean was 1.98) and standard deviation was 0.97. The second variable was service animal with a score mean of 1.09 and limited variance in participant's responses.

Table (4): The services and facilities provided for persons with disabilities in the resort $(n=84)$.

\begin{tabular}{|c|c|c|c|c|}
\hline Disabled Services and Facilities & \multicolumn{2}{|c|}{ Mean* } & S.D. & Rank \\
\hline \multirow[t]{3}{*}{ Service animal } & 3 star & 1.00 & 0.001 & \multirow{4}{*}{8} \\
\hline & 4 star & 1.00 & 0.001 & \\
\hline & 5 star & 1.15 & 0.53 & \\
\hline Overall mean & \multicolumn{2}{|c|}{1.09} & 0.43 & \\
\hline \multirow[t]{3}{*}{ Trained staff } & 3 star & 2.33 & 0.57 & \multirow{4}{*}{1} \\
\hline & 4 star & 2.37 & 3.96 & \\
\hline & 5 star & 2.77 & 0.41 & \\
\hline Overall mean & \multicolumn{2}{|c|}{2.95} & 2.3 & \\
\hline \multirow[t]{3}{*}{ Corridors for guests with disabilities. } & 3 star & 1.66 & 1.15 & \multirow{4}{*}{7} \\
\hline & 4 star & 1.63 & 0.92 & \\
\hline & 5 star & 2.17 & 0.94 & \\
\hline Overall mean & \multicolumn{2}{|c|}{1.98} & 0.97 & \\
\hline \multirow{3}{*}{$\begin{array}{l}\text { Reception and reservation area for guests with } \\
\text { disabilities. }\end{array}$} & 3 star & 1.67 & 1.15 & \multirow{4}{*}{5} \\
\hline & 4 star & 1.81 & 1.00 & \\
\hline & 5 star & 2.26 & 0.93 & \\
\hline Overall mean & \multicolumn{2}{|c|}{2.09} & 0.98 & \\
\hline \multirow[t]{3}{*}{ Public toilets for guests with disabilities. 2.14} & 3 star & 1.66 & 1.15 & \multirow{4}{*}{4} \\
\hline & 4 star & 2.07 & 0.99 & \\
\hline & 5 star & 2.20 & 0.95 & \\
\hline Overall mean & \multicolumn{2}{|c|}{2.14} & 0.97 & \\
\hline \multirow[t]{3}{*}{ Accessible elevators for guests with disabilities. } & 3 star & 1.00 & 0.001 & \multirow{4}{*}{6} \\
\hline & 4 star & 1.77 & 0.97 & \\
\hline & 5 star & 2.16 & 0.94 & \\
\hline Overall mean & & & 0.97 & \\
\hline \multirow[t]{3}{*}{ Accessible rooms for guests with disabilities. } & 3 star & 3.00 & 0.001 & \multirow{4}{*}{3} \\
\hline & 4 star & 2.88 & 0.32 & \\
\hline & 5 star & 2.94 & 0.23 & \\
\hline Overall mean & & & 0.26 & \\
\hline \multirow[t]{3}{*}{ Special toilets in rooms of guests with disabilities. } & 3 star & 3.00 & 0.001 & \multirow{4}{*}{2} \\
\hline & 4 star & 2.93 & 0.26 & \\
\hline & 5 star & 2.95 & 0.23 & \\
\hline Overall mean & & & 0.24 & \\
\hline \multirow{3}{*}{$\begin{array}{l}\text { Special equipments for guests with disabilities such as } \\
\text { wheelchairs. }\end{array}$} & 3 star & 3.00 & 0.001 & \multirow{4}{*}{3} \\
\hline & 4 star & 2.89 & 0.42 & \\
\hline & 5 star & 2.94 & 0.30 & \\
\hline Overall mean & \multicolumn{2}{|c|}{2.93} & 0.34 & \\
\hline
\end{tabular}


Table 5 presents the one-way ANOVA to analyze the differences between three-star, four-star and five-star resorts with regard to providing disabled services and facilities. The results showed that there were two statistically significant differences between resorts grades (i.e. corridors and accessible elevators) and providing disabled services and facilities for PWD. The LSD (Least Significant Difference) and Games-Howell post-hoc tests show that the accessible corridors was significantly higher among five star resorts (mean 2.27) than other resorts grades; four star resorts (mean 1.66) and three star resorts (mean 1.63).

The LSD and Games-Howell post-hoc tests also show that the accessible elevators was significantly higher among five star resorts (mean 2.17) than other resorts grades; four star resorts (mean 1.77) and three star resorts (mean $1.00)$.

The results of the ANOVA test (see Table 5) also revealed that there was a statistically significant difference between resorts regions in regard of disabled services and facilities. The LSD and Games-Howell post-hoc tests also show that the service animal elevators was significantly higher among Cairo and Luxor resorts (mean 1.80) than other resorts regions (mean 1.00).

Table (5): Differences between resorts grades and resorts regions in relation to disabled services and facilities

\begin{tabular}{|lcccc|}
\hline \multirow{2}{*}{\multicolumn{1}{c}{ Disabled Services and Facilities }} & \multicolumn{2}{c}{ Resorts grades } & \multicolumn{2}{c|}{ Resorts regions } \\
\cline { 2 - 5 } & F & Sig. & F & Sig. \\
\hline Service animal & 1.157 & 0.32 & 9.162 & $0.00^{*}$ \\
\hline Trained staff & 0.727 & 0.486 & 0.279 & 0.923 \\
\hline Corridors for guests with disabilities. & 3.068 & $0.05^{*}$ & 0.776 & 0.57 \\
\hline $\begin{array}{l}\text { Reception and reservation area for guests with } \\
\text { disabilities. }\end{array}$ & 2.225 & 0.115 & 1.065 & 0.386 \\
\hline Public toilets for guests with disabilities. & 0.528 & 0.592 & 0.330 & 0.893 \\
\hline Accessible elevators for guests with disabilities. & 3.274 & $0.043^{*}$ & 1.330 & 0.26 \\
\hline Accessible rooms for guests with disabilities. & 0.526 & 0.593 & 0.378 & 0.862 \\
\hline Special toilets in rooms of guests with disabilities. & 0.149 & 0.862 & 0.422 & 0.832 \\
\hline $\begin{array}{l}\text { Special equipments for guests with disabilities } \\
\text { Such as wheelchairs. }\end{array}$ & 0.305 & 0.738 & 0.218 & 0.954 \\
\hline
\end{tabular}

* Statistically significant difference.

\subsection{Advantages of providing services and facilities of PWD in resorts}

The purpose of this question was to identify the feasibility of providing services and facilities of guests with disabilities from the resorts manager's opinion.

The results (table 6) showed that the first advantage of providing services and facilities for PWD was improving the perceived image of the resort with a score mean of 2.82 and slight standard deviation (0.38). There were two issues were ranked as the second advantage; the first one was attracting an important segment of Tourists (persons with disabilities) in the resort with a mean score of 2.79 with a standard deviation of (0.40). The second one was Achieving satisfaction of guests with disabilities with a mean score of 2.79 with a standard deviation of $(0.40)$. 
The third advantage was increasing of the resort's profit with a mean score of 2.67 and standard deviation of 0.60 . The fourth advantage was increasing loyalty of guests with disabilities towards the resort with a mean score of 2.60 with a standard deviation of $(0.65)$.

Table (6): The advantages of providing services and facilities of guests with disabilities in the resort $(n=84)$.

\begin{tabular}{|c|c|c|c|c|}
\hline \multirow{4}{*}{$\begin{array}{l}\text { Advantages of disables services and facilities } \\
\text { Attracting an important segment of Tourists } \\
\text { (persons with disabilities) in the resort. }\end{array}$} & \multicolumn{2}{|c|}{ *Mean } & \multirow{2}{*}{$\begin{array}{c}\text { S.D. } \\
0.001\end{array}$} & \multirow{4}{*}{$\begin{array}{c}\text { Rank } \\
2\end{array}$} \\
\hline & $3 \mathrm{star}$ & 3.00 & & \\
\hline & $4 \mathrm{star}$ & 2.85 & 0.36 & \\
\hline & $5 \mathrm{star}$ & 2.75 & 0.43 & \\
\hline Overall mean & \multicolumn{2}{|c|}{2.79} & 0.40 & \\
\hline \multirow[t]{3}{*}{ Improving the perceived image of the resort. } & 3 star & 2.66 & 0.57 & \multirow{4}{*}{1} \\
\hline & 4 star & 2.81 & 0.39 & \\
\hline & $5 \mathrm{star}$ & 2.83 & 0.37 & \\
\hline Overall mean & & & 0.38 & \\
\hline \multirow{3}{*}{$\begin{array}{lllll}\begin{array}{l}\text { Achieving } \\
\text { disabilities. }\end{array} & \text { satisfaction of } & \text { guests with } \\
& & & \end{array}$} & 3 star & 3.00 & 0.001 & \multirow{4}{*}{2} \\
\hline & 4 star & 2.74 & 0.44 & \\
\hline & $5 \mathrm{star}$ & 2.81 & 0.39 & \\
\hline Overall mean & & & 0.40 & \\
\hline \multirow{3}{*}{$\begin{array}{l}\text { Increasing loyalty of guests with disabilities } \\
\text { towards the resort. }\end{array}$} & $3 \mathrm{star}$ & 3.00 & 0.001 & \multirow{4}{*}{4} \\
\hline & $4 \mathrm{star}$ & 2.55 & 0.69 & \\
\hline & 5 star & 2.61 & 0.65 & \\
\hline Overall mean & & & 0.65 & \\
\hline \multirow[t]{3}{*}{ Increasing of the resort's profit. } & 3 star & 3.00 & 0.001 & \multirow{4}{*}{3} \\
\hline & 4 star & 2.70 & 0.54 & \\
\hline & $5 \mathrm{star}$ & 2.64 & 0.64 & \\
\hline Overall mean & & & 0.60 & \\
\hline
\end{tabular}

*Mean of advantages of providing services and facilities of guests with disabilities in the resort where $1=$ disagree, $2=$ neutral and $3=$ agree.

Table 7 showed the results of a one-way ANOVA test to examine the differences between resorts grades and resorts regions with regard of advantages of providing disabled services and facilities in the resort.

The results revealed that the significance level were more than 0.05 (the significance level were $0.43,0.76,0.50,0.54$ and 0.60 ) that means that there were no statistically significant differences between resorts grades with regard of advantages of providing disabled services and facilities in the resort.

The results of the ANOVA test (table 7) showed that there were some of statistically significant differences between resorts regions with regard of advantages of providing disabled services and facilities in the resort. The LSD (Least Significant Difference) and Games-Howell post-hoc tests show that attracting an important segment of Tourists (persons with disabilities) in the resort was significantly higher among Sharm El-Sheikh resorts (mean 3.00) than other resorts regions; Hurghada resorts (mean 2.75), Aswan resorts (mean 2.66), Luxor and Cairo resorts (2.60) and Sukhna resorts (mean 2.50). The LSD and Games-Howell post-hoc tests also show that improving the perceived image of the resort was significantly higher among Sharm El-Sheikh resorts (mean 3.00) than other resorts regions; Cairo resorts (mean 2.80), Hurghada resorts (mean 2.77), Aswan resorts (mean 2.66), Luxor resorts (2.60) and Sukhna resorts (mean 2.50). 
Table (7): Differences between resorts grades and resorts regions with regard of advantages of providing disabled services and facilities in the resort.

\begin{tabular}{|lcccc|}
\hline $\begin{array}{l}\text { Advantages of Disabled Services and } \\
\text { Facilities }\end{array}$ & \multicolumn{2}{c}{ Resorts grades } & \multicolumn{2}{c|}{ Resorts regions } \\
\cline { 2 - 6 } & F & Sig. & F & Sig. \\
\hline $\begin{array}{l}\text { Attracting an important segment of Tourists } \\
\text { persons with disabilities) in the resort. }\end{array}$ & 0.859 & 0.43 & 3.092 & $0.01^{*}$ \\
\hline Improving the perceived image of the resort. & 0.267 & 0.76 & 2.902 & $0.02^{*}$ \\
\hline $\begin{array}{l}\text { Achieving satisfaction of guests with } \\
\text { disabilities. }\end{array}$ & 0.687 & 0.50 & 3.371 & $0.008^{*}$ \\
\hline $\begin{array}{l}\text { Increasing loyalty of guests with disabilities } \\
\text { towards the resort. }\end{array}$ & 0.611 & 0.54 & 4.739 & $0.001^{*}$ \\
\hline Increasing of the resort's profit. & 0.510 & 0.60 & 2.228 & 0.06 \\
\hline
\end{tabular}

* Statistically significant difference.

The LSD and Games-Howell post-hoc tests also show that achieving satisfaction of guests with disabilities was significantly higher among Sharm El-Sheikh resorts (mean 3.00) than other resorts regions; Hurghada resorts (mean 2.77), Aswan and Sukhna resorts (mean 2.66), Luxor resorts (2.60) and Cairo resorts (mean 2.80).

The LSD and Games-Howell post-hoc tests reveal that increasing loyalty of guests with disabilities towards the resort was significantly higher among Sharm El-Sheikh resorts (mean 3.00) than other resorts regions; Aswan (mean 2.66), Hurghada resorts (mean 2.47), Cairo resorts (mean 2.40), Luxor resorts (2.20) and Sukhna resorts (mean 2.00). The results of the ANOVA test (table 9) also showed that that increasing of the resort's profit had significance level more than 0.05 (the significance level was 0.60 ) that means that there were no statistically significant differences between resorts regions with regard of this issue.

\subsection{Challenges of providing services and facilities for PWD in the resort}

The aim of this question was to declare the barriers or challenges that face the resorts of providing services and facilities for guests with disabilities. The results (Table 8 ) indicated that there were three neutral challenges of providing services and facilities for guests with disabilities in resorts. The first challenge was lack of tourists with disabilities (mean score 2.57) and standard deviation of 0.79. The second challenge was lack of information on how to improve services and facilities of persons with disabilities in practical ways (mean score 2.39) and a standard deviation of 0.84. The third challenge is lack of cooperation between the resort and tourism authorities in providing suitable services and facilities for persons with disabilities (mean score of 2.12) and standard deviation of 0.96 . There were four disagreeing challenges of providing services and facilities for guests with disabilities in the resort. The first one was lack of appropriate infrastructure and superstructure (Mean score 1.99) and standard deviation 0.87 . The second one was high cost of services and facilities for persons with disabilities with a mean score of 1.98 and standard deviation 0.94. The third one was failure to adopt the Egyptian Hotel New Norms for disabilities with a mean score of 1.46 and standard deviation 0.83 . 
The fourth one was unqualified staff to serve guests with disabilities with a mean score of 1.37 and standard deviation 0.63 .

Table (8): Challenges of providing services and facilities for guests with disabilities in the resort $(n=84)$.

\begin{tabular}{|c|c|c|c|c|}
\hline $\begin{array}{l}\text { Challenges of providing disabled services and } \\
\text { facilities }\end{array}$ & \multicolumn{2}{|c|}{ *Mean } & S.D. & Rank \\
\hline \multirow{3}{*}{$\begin{array}{l}\text { The high cost of services and facilities provided for } \\
\text { persons with disabilities. } 1.98\end{array}$} & 3 star & 2.66 & 0.57 & \multirow{4}{*}{5} \\
\hline & 4 star & 2.33 & 0.87 & \\
\hline & 5 star & 1.76 & 0.93 & \\
\hline Overall mean & \multicolumn{2}{|c|}{1.98} & 0.94 & \\
\hline \multirow{3}{*}{$\begin{array}{l}\text { Lack of appropriate infrastructure and } \\
\text { superstructure for providing services and facilities } \\
\text { of persons with disabilities. }\end{array}$} & $3 \mathrm{star}$ & 3.00 & 0.001 & \multirow{4}{*}{4} \\
\hline & 4 star & 2.26 & 0.85 & \\
\hline & $5 \mathrm{star}$ & 1.79 & 0.83 & \\
\hline Overall mean & \multicolumn{2}{|c|}{1.99} & 0.87 & \\
\hline \multirow{3}{*}{$\begin{array}{l}\text { Lack of cooperation between the resort and tourism } \\
\text { authorities in providing suitable services and } \\
\text { facilities for persons with disabilities. }\end{array}$} & 3 star & 3.00 & 0.001 & \multirow{4}{*}{3} \\
\hline & 4 star & 2.18 & 0.96 & \\
\hline & 5 star & 2.03 & 0.97 & \\
\hline Overall mean & \multicolumn{2}{|c|}{2.12} & 0.96 & \\
\hline \multirow{3}{*}{ Unqualified staff to serve guests with disabilities. } & 3 star & 2.33 & 0.57 & \multirow{3}{*}{7} \\
\hline & 4 star & 1.66 & 0.83 & \\
\hline & $5 \mathrm{star}$ & 1.16 & 0.37 & \\
\hline Overall mean & \multicolumn{2}{|c|}{1.37} & 0.63 & \\
\hline \multirow{3}{*}{$\begin{array}{l}\text { Lack of information on how to improve services and } \\
\text { facilities of persons with disabilities in practical } \\
\text { ways. }\end{array}$} & 3 star & 3.00 & 0.001 & \multirow{4}{*}{2} \\
\hline & 4 star & 2.29 & 0.91 & \\
\hline & $5 \mathrm{star}$ & 2.40 & 0.81 & \\
\hline Overall mean & \multicolumn{2}{|c|}{2.39} & 0.84 & \\
\hline \multirow{3}{*}{ Limited number of tourists with disabilities. } & $3 \mathrm{star}$ & 3.00 & 0.001 & \multirow{4}{*}{1} \\
\hline & 4 star & 2.37 & 0.92 & \\
\hline & $5 \mathrm{star}$ & 2.65 & 0.73 & \\
\hline Overall mean & & & 0.79 & \\
\hline \multirow{3}{*}{ Failure to adopt the Egyptian Hotel New Norms. } & 3 star & 1.66 & 1.15 & \multirow{4}{*}{6} \\
\hline & 4 star & 1.62 & 0.92 & \\
\hline & $5 \mathrm{star}$ & 1.37 & 0.75 & \\
\hline Overall mean & \multicolumn{2}{|c|}{1.46} & 0.82 & \\
\hline
\end{tabular}

*Mean of challenges of providing services and facilities for guests with disabilities in the resort. Where $1=$ disagree, $2=$ neutral and $3=$ agree.

Table 9 presents the one-way ANOVA to analyze the differences between resorts grades with respect to the challenges that face the resorts of providing disabled services and facilities. The results showed that there were some of statistically significant differences between resorts grades. The LSD (Least Significant Difference) and Games-Howell post-hoc tests show that the high cost of services and facilities for persons with disabilities was significantly higher among three star resorts (mean 2.66) than other resorts grades; four star resorts (mean 2.33) and five star resorts (mean 1.48).

The LSD and Games-Howell post-hoc tests also show that Lack of appropriate infrastructure and superstructure for providing services and facilities of persons with disabilities was significantly higher among three star resorts (mean 3.00) than other resorts grades; four star resorts (mean 2.25) and five star resorts (mean 1.79). 
The LSD and Games-Howell post-hoc tests also show that unqualified staff to serve guests with disabilities was significantly higher among three star resorts (mean 2.33) than other resorts grades; four star resorts (mean 1.66) and five star resorts (mean 1.16).

The results of the ANOVA test (table 9) reveal that the significance levels were more than 0.05 that means that there were no statistically significant differences between resorts regions with respect to the challenges that face the resorts of providing disabled services and facilities.

Table (9): Differences between resorts grades and resorts regions with respect to the challenges that face the resorts of providing services and facilities for guests with disabilities.

\begin{tabular}{|c|c|c|c|c|}
\hline \multirow{2}{*}{$\begin{array}{l}\text { Challenges of Providing disabled Services } \\
\text { and Facilities }\end{array}$} & \multicolumn{2}{|c|}{ Resorts grades } & \multicolumn{2}{|c|}{ Resorts Regions } \\
\hline & $\mathbf{F}$ & Sig. & $\mathbf{F}$ & Sig. \\
\hline $\begin{array}{l}\text { The high cost of services and facilities for } \\
\text { persons with disabilities. }\end{array}$ & 4.514 & $0.01 *$ & 0.600 & 0.70 \\
\hline $\begin{array}{l}\text { Lack of appropriate infrastructure and } \\
\text { superstructure for providing services and } \\
\text { facilities of persons with disabilities. }\end{array}$ & 5.099 & $0.00 *$ & 0.801 & 0.55 \\
\hline $\begin{array}{l}\text { Lack of cooperation between the resort and } \\
\text { tourism authorities in providing suitable } \\
\text { services and facilities for persons with } \\
\text { disabilities. }\end{array}$ & 1.538 & 0.22 & 0.521 & 0.76 \\
\hline $\begin{array}{l}\text { Unqualified staff to serve guests with } \\
\text { disabilities. }\end{array}$ & 11.442 & $0.00 *$ & 0.082 & 0.99 \\
\hline $\begin{array}{l}\text { Lack of information on how to improve } \\
\text { services and facilities of persons with } \\
\text { disabilities in practical ways. }\end{array}$ & 0.978 & 0.38 & 1.459 & 0.21 \\
\hline Limited number of tourists with disabilities. & 1.569 & 0.21 & 1.011 & 0.41 \\
\hline $\begin{array}{l}\text { Failure to adopt the Egyptian Hotel New } \\
\text { Norms. }\end{array}$ & 0.975 & 0.38 & 1.829 & 0.11 \\
\hline
\end{tabular}

* Statistically significant difference.

\subsection{Reasons for lack of services and facilities for PWD in resorts in Egypt}

This question was directed to the (22) resorts which do not provide disabled services and facilities to focus on the main reasons of lack of services and facilities provided for PWD. The results (table 10) showed that the first reasons of lack of disabled services and facilities was the high cost of services and facilities for persons with disabilities with a mean score of 2.82 and slight standard deviation (0.50). The second reason was the lack of culture of dealing with tourists with disabilities with a mean score of 2.79 with a standard deviation of (0.40). The second one was Achieving satisfaction of guests with disabilities with a mean score of 2.77 with a standard deviation of $(0.53)$.

The third reason was the lack of marketing for persons with disabilities tourism with a mean score of 2.68 and standard deviation of 0.47 . The fourth reason was lack of tourists with disabilities (mean 2.59) with a standard deviation of $(0.50)$. The fifth reason was non consideration of services and facilities in the planning of infrastructure and superstructure with a mean score of 2.55 and slight standard deviation (0.74). 
The sixth reason was failure in follow of the Egyptian hotel new norms (mean 2.18) and there was no significant variance of standard deviation (1.00).

Table (10): Reasons of lack of services and facilities for persons with disabilities in the Egyptian resorts $(n=22)$.

\begin{tabular}{|c|c|c|c|c|}
\hline Reasons for lack of disabled services and facilities & & & S.D. & Rank \\
\hline & 3 star & 2.70 & 0.67 & \\
\hline The lack of culture of dealing with tourists with & 4 star & 2.90 & 0.30 & 2 \\
\hline & 5 star & 2.00 & 0.001 & 2 \\
\hline Overall mean & & & $\mathbf{0 . 5 3}$ & \\
\hline & 3 star & 2.50 & 0.52 & \\
\hline The limited number of tourists with disabilities. & 4 star & 2.63 & 0.50 & 1 \\
\hline & 5 star & 3.00 & 0.001 & 4 \\
\hline Overall mean & & & $\mathbf{0 . 5 0}$ & \\
\hline The lock of morloting for porcons with dic & 3 star & 2.70 & 0.48 & \\
\hline The lack of marketing for persons with disabilities & 4 star & 2.72 & 0.46 & 3 \\
\hline & 5 star & 2.00 & 0.001 & 3 \\
\hline Overall mean & & & $\mathbf{0 . 4 7}$ & \\
\hline & 3 star & 2.40 & 0.84 & \\
\hline Non consideration of services and facilities in the & 4 star & 2.63 & 0.67 & \\
\hline & 5 star & 3.00 & 0.001 & 5 \\
\hline Overall mean & & & 0.74 & \\
\hline & 3 star & 2.70 & 0.67 & \\
\hline The high cost of services and facilities for persons with & 4 star & 2.90 & 0.30 & \\
\hline & 5 star & 3.00 & 0.001 & 1 \\
\hline Overall mean & & & $\mathbf{0 . 5 0}$ & \\
\hline & 3 star & 2.20 & 1.03 & \\
\hline Failure to adopt the Egyptian Hotel New Norms. & 4 star & 2.27 & 1.00 & \\
\hline & 5 star & 1.00 & 0.001 & 6 \\
\hline Overall mean & & & 1.00 & \\
\hline
\end{tabular}

*Mean of reasons of lack of services and facilities for PWDs where $1=$ disagree, $2=$ neutral and $3=$ agree.

The results of the ANOVA test (table 11) revealed that the significance levels were more than 0.05 that means that there were no statistically significant differences between resorts regions and resorts grades with respect to the reasons of lack of services and facilities for persons with disabilities in the resort.

Table (11): Differences between resorts grades and resorts regions in regard of reasons of lack of disabled services and facilities in the resort.

\begin{tabular}{|c|c|c|c|c|}
\hline \multirow{2}{*}{$\begin{array}{c}\text { Reasons of Lack of disabled Services and } \\
\text { Facilities }\end{array}$} & \multicolumn{2}{|c|}{ Resorts grades } & \multicolumn{2}{|c|}{ Resorts Regions } \\
\hline & $\mathbf{F}$ & Sig. & $\mathbf{F}$ & Sig. \\
\hline $\begin{array}{l}\text { The lack of culture of dealing with tourists with } \\
\text { disabilities. }\end{array}$ & 1.621 & 0.22 & 0.992 & 0.38 \\
\hline Lack of tourists with disabilities. & 0.514 & 0.60 & 1.291 & 0.29 \\
\hline $\begin{array}{l}\text { The lack of marketing for persons with disabilities } \\
\text { tourism. }\end{array}$ & 1.089 & 0.35 & 0.260 & 0.77 \\
\hline $\begin{array}{l}\text { Non consideration of services and facilities in the } \\
\text { planning of infrastructure and superstructure. }\end{array}$ & 0.442 & 0.64 & 1.084 & 0.35 \\
\hline $\begin{array}{l}\text { The high cost of services and facilities for persons } \\
\text { with disabilities. }\end{array}$ & 0.500 & 0.61 & 0.500 & 0.61 \\
\hline $\begin{array}{l}\text { Failure in follow of the Egyptian Hotel New } \\
\text { Norms. }\end{array}$ & 0.716 & 0.50 & 1.527 & 0.24 \\
\hline
\end{tabular}




\section{Suggestions for improving disabled services and facilities}

The purpose of this question was to gather any additional suggestions to improve services and facilities provided for persons with disabilities in the Egyptian resorts through an open-ended question. Most of responses could be concluded in the following recommendations:

- The Egyptian Ministry of Tourism is advised to promote for the available hotels and destinations that provide services and facilities for PWD in Egypt.

- The Egyptian Ministry of Tourism is recommended to design data base or website shows the availability of services and facilities that are provided in Egypt to serve PWD sector; this website consists of accessible hotels and destinations that contains accessible facilities and make groups offers in this page to encourage accessible tourism.

\section{Conclusions}

This research aimed to explore and evaluate services and facilities provided for persons with disabilities in resorts in Egypt. The results revealed that a large proportion of the investigated resorts have provided disabled services and facilities where five-star resorts provided more disabled services and facilities than four and three star resorts. Guests with disabilities represented a significant number of resorts overall guests despite the limited disabled services and facilities available in Egyptian resorts. The study also showed that disabled services and facilities provided in resorts were focused more on tangible facilities (i.e. public toilets, accessible rooms and special equipments for PWD such as wheelchairs) rather than intangible services (such as qualified staff and service animal).

The research also explored management perception of disabled services and facilities in resorts through discussing operational advantages and obstacles of providing such facilities. The findings showed some significant advantages of providing services and facilities for PWD, such as: improving the perceived image of the resort; achieving satisfaction of guests with disabilities. The findings also revealed that there were some challenges that hindered providing disabled services and facilities in the Egyptian resorts, including: lack of tourists with disabilities; lack of established practices and information about operationalizing and improving disabled services and facilities in resorts. The results also explored a number of reasons for providing limited services and facilities for PWDs, such as: high cost of disabled services and facilities; lack of culture of dealing with disabled tourists.

\section{Limitation and Recommendations for Further Research}

Resorts managers are encouraged to target and attract untraditional market segments, such as accessible market/PWDs through providing appropriate services and facilities that enable a pleasant and comfortable accommodation experience for them. Resorts managers are also advised to explore the needs, wants and preferences of guests with disabilities during their stay in the resort. It is also worth recommending that resort managers should adopt the standards of the Ministry of Tourism which requires providing certain disables services 
and facilities, known as New Norms NN. Qualified staff to deal with PWD is another important aspect that should be considered when it comes to serving PWDs. The Egyptian Ministry of Tourism is advised to promote Egypt as an accessible destination through focusing on hotels and cities that provide services and facilities for PWD in Egypt. The Egyptian Ministry of Tourism is recommended to develop an online database or regular website that shows that promotes disabled services and facilities provided in Egypt to attract and serve PWD segment.

Such website can include accessible hotels, resorts, sightseeing that provide accessible facilities and services; as well as providing promotional offers for PWDs. Last but not least, The Egyptian government is also recommended to make serious improvements on infrastructure and superstructure, especially in the accessible destinations, to fit PWDs' needs.

The first limitation was related to literature review where there was a lack of books and data sources in relation to disabled services and facilities in the hospitality industry. The second limitation was related to use of the quantitative approach although its extensive and effective results but using the qualitative approach would have provided more diverse and enriching results.

Further research could be conducted using qualitative approach to enrich and expand more results. Further research also, could be conducted on handling services and facilities provided for persons with disabilities in hotels comparing between independent and chain hotels. Further research could be conducted to investigate guest satisfaction with provided disabled services and facilities in hotels or resorts. Finally, further research investigated marketing of disabled services and facilities in Egyptian hotels.

\section{References}

Ali, M., A. (2008). The Impact of Cultural Differences between German and Italian Guests on their Perceptions towards Hotel Service Quality. PHD Research Thesis in Hotel Management, Faculty of Tourism and Hotels Management, Helwan University.

Bacon, PH., Richard, S. (2011). Resorts - A Focus on Value. HVS Global hospitality services, Madrid. \{on line $\}$ Available from: https://www.hvs.com/Content/3085.pdf. Retrieved on \{2/10/2016\}.

Breedt, T. F. (2007). The Need for Disabled Friendly Accommodation in South Africa. . Master Research Thesis of Business Administration at the Potchefstroom campus of the North-West University. \{on line\} Available from:

http://citeseerx.ist.psu.edu/viewdoc/download?doi=10.1.1.463.6750\&rep=rep1 \&type=pdf. Retrieved on $\{11 / 11 / 2016\}$.

Brun, A. (2010). Service Quality and Customer Satisfaction in the Hotel Industry. $\quad$ on line $\} \quad$ Available from: https://www.politesi.polimi.it/bitstream/10589/13105/1/2010_10_Le.pdf Retrieved on $\{21 / 9 / 2016\}$.

Bloemer, J., Ruyter, K., \& Wetzels, M. (1998). Linking perceived service quality and service loyalty: a multi-dimensional perspective. European Journal of Marketing, $(33)(11,12)$. \{ on line $\}$ Available from: https://www.dsef.org/wp- 
content/uploads/2012/01/Linking_perceived_service_quality_and_service_loya lty_a_mult.pdf . Retrieved on $\{28 / 10 / 2016\}$.

Chen, J. (2005). Uses of Hospitality and Leisure Services: Voices of Visitors with Disabilities. Journal of Advances in Hospitality and Leisure, (1) Emerald Group Publishing Limited, pp. 89 - 102. \{on line\} Available from: http://dx.doi.org/10.1016/S1745-3542(04)01006-9 . Retrieved on \{2/11/2016\}. City of Mississauga (2015). Facility Accessibility Design Standards. \{online\}. Available from: http://www7.mississauga.ca/Departments/Marketing/Websites/Accessibility/Mi ssissauga_FADS.html. Retrieved on $\{20 / 11 / 2016\}$.

City of Toronto (2004). Accessibility Design Guidelines. \{on line\}. Available from:

https://www1.toronto.ca/static_files/equity_diversity_and_human_rights_office /pdf/accessibility_design_guidelines.pdf. Retrieved on \{20/11/2016\}.

Department of Justice (2010). Americans with Disabilities Act, Design Standards. $\quad$ on line . Available from: www.ada.gov/2010ADAstandards_index.htm. Retrieved on \{20/11/2016\}.

Department of Justice (2010). Americans with Disabilities Act. \{on line\}. Available from: http://www.ada.gov/regs2010/service_animal_qa.html. Retrieved on $\{15 / 10 / 2016\}$.

Dracy, S. \& Pegg, S. (2010). Towards Strategic Intent: Perception of Disability Service Provision amongst Hotel Accommodation Sector Managers. \{on line\}. Available from: http://www.academia.edu/357557/Towards_Strategic_Intent_Perceptions_of_D isability_Service_Provision_Amongst_Hotel_Accommodation_Sector_Manage rs. Retrieved on $\{13 / 11 / 2016\}$.

European Commission (2017). Internal market, Industry, Entrepreneurship and SMEs. $\quad$ On line $\}$ Available from: http://ec.europa.eu/growth/sectors/tourism/offer/accessible_en. Retrieved on $\{24 / 1 / 2017\}$.

European Disability Forum (2001). EDF position paper on tourism: Framing the future of European tourism. \{on line\} Available from: http://www.edffeph. Org/Papers/pospaper/01-13/EDF01-13 EDF response European Tourism. Pdf. Retrieved on $\{7 / 11 / 2016\}$.

Greater London Authority (2010). Accessible Hotels in London. \{on line\}. Available from: www.london.gov.uk. Retrieved on $\{5 / 12 / 2016\}$.

Hagras, H. (2005). Definitions of Disability and Disability Policy in Egypt. \{on line\} Available from: http://disabilitystudies.leeds.ac.uk/archiveuk/Barnes/emw\%20Chapter\%2010.pdf. Retrieved on $\{15 / 2 / 2016\}$.

Ministry of Statistics and Programs Implementation in India (MOSPI), disability statistical data in India (2011). \{on line\} Available from: http://mospi.nic.in/Mospi_New/upload/disablity_india_statistical_data_11mar2 011/Chapter\%203\%20Definition_\%20Disability.pdf. Retrieved on $\{15 / 2 / 2016\}$.

Ministry of Tourism in Egypt (2010). New Norms for Resorts Criteria. 
Nestoroska, I. \& Petrovska, I. (2014). Staff Training in Hospitality Sector as a Benefit for Improved Service Quality. \{on line\}. Available from: http://www.fthm.uniri.hr/files/Kongresi/THI/Papers/2014/THI_May2014_437t o448.pdf. Retrieved on $\{15 / 10 / 2016\}$.

Peniston, L. C. (1996). Hotel accessibility and accommodations for people with disabilities. $\quad$ on line . Available from: http://0811lxujw.1104.y.http.web.b.ebscohost.com.mplb.ekb.eg/ehost/detail/det ail?sid=5b715575-95fb-4588-9de3e8fb305f9eb1\%40sessionmgr105\&vid=0\&hid $=101 \&$ bdata $=$ JnNpdGU9ZWhvc 3QtbGl2ZQ\%3d\%3d\#AN=9701131446\&db=a9h. Retrieved on $\{3 / 11 / 2016\}$. Popiel, M. (2014). Paving the Way to Accessible Tourism on The Example of Krakow. European Journal of Tourism, Hospitality and Recreation Special Issue, 55-71. $\quad$ on line $\quad$ Available from: http://www.ejthr.com/ficheiros/2014/SpecialIssue/EJTHR_Volume5_SE_Art3. pdf. Retrieved on $\{2 / 10 / 2015\}$.

Poria, Y., Reichel, A., \& Brandt, Y. (2011). Dimensions of hotel experience of people with disabilities: an exploratory study. International Journal of Contemporary Hospitality Management, (23) (5). \{on line\} Available from: http://in.bgu.ac.il/SiteAssets/Pages/news/people-with-disabilities-hotel experience/Dimensions\%20of\%20hotel\%20xperience\%20of\%20people\% 0with\%20disabilities.pdf. Retrieved on $\{22 / 1 / 2016\}$.

Powell, Th., C. (1995). Total Quality Management as Competitive Advantage: A Review and Empirical Study. Strategic management Journal, (16), (1). \{on line\} Available from: www.thomaspowell.co.uk/article_pdfs/TQM_as_CA.pdf. Retrieved on $\{28 / 10 / 2016\}$.

Russell, R. V. (1996). How the lodging industry complies with ADA requirements. $\quad$ on line $\}$ Available from: http://0811lxujw.1104.y.http.web.b.ebscohost.com.mplb.ekb.eg/ehost/detail/det ail?sid=68d328f4-ba12-498b-9ad8-

38816a274c22\%40sessionmgr102\&vid $=0 \&$ hid $=101 \&$ bdata $=$ JnNpdGU9ZWhv c3QtbGl2ZQ\%3d\%3d\#AN=9701131448\&db=a9h. Retrieved on $\{3 / 11 / 2016\}$. Standards New Zealand (2001). Design for Access and Mobility -Buildings and Associated Facilities. \{on line . Available from: https://law.resource.org/pub/nz/ibr/nzs.4121.2001.svg.html. Retrieved on $\{22 / 11 / 2016\}$.

The European Network for Accessible Tourism (ENAT) (2015). EU Study: Stronger Commitment Needed to Meet Growing Accessible Tourism Demand in Europe. $\quad$ on line $\}$ Available from: http://www.accessibletourism.org/?i=enat.en.press.1741. Retrieved on $\{22 / 1 / 2017\}$.

The European Network for Accessible Tourism (ENAT) (2015). Lonely Planet and the European Network for Accessible Tourism (ENAT) Join Forces to Promote Inclusive Tourism Around the World. \{on line\}. Available from: http://www.accessibletourism.org/?i=enat.en.press.1810. Retrieved on $\{22 / 1 / 2017\}$. 
United Nations, economic and social commission for western Asia (2003). Accessibility for the

Disabled,

A Design Manual for a Barrier Free Environment. \{on line\} Available from: http://www.un.org/esa/socdev/enable/designm. Retrieved on \{2014-06-27\}.

United States Access Board (2002). ADA Accessibility Guidelines for Buildings and Facilities (ADAAG). \{on line $\}$. Available from: https://www.access-board.gov/guidelines-and-standards/buildings-andsites/about-the-ada-standards/background/adaag. Retrieved on $\{22 / 11 / 2016\}$. United States Access Board (2004). Americans with Disabilities Act and Architectural Barriers Act Accessibility Guidelines. \{on line\}. Available from: https://www.si.edu/Content/Accessibility/Americans-Disabilities-Act.pdf.

Retrieved on $\{10 / 12 / 2016\}$.

United States Agency for International Development (USAID Ethiopia). Disability Inclusion Strategy (2011). \{on line $\}$ Available from: http://ethiopia.usaid.gov/sites/default/files/images/USAID_Disability_Strategy. pdf. Retrieved on $\{5 / 2 / 2016\}$.

World Bank (2002). Country Profile Disability. Japan International Cooperation Agency Planning and Evaluation Department. \{on line\} Available from:http://siteresources.worldbank.org/DISABILITY/Resources/Regions/Afri ca/JICA_Ethiopia.pdf. Retrieved on $\{3 / 1 / 2016\}$.

World Health Organization (2011). World report on disability. \{on line\} Available

from: http://www.who.int/disabilities/world_report/2011/chapter1.pdf. Retrieved on $\{29 / 1 / 2016\}$.

World Tourism Organization and Fundación ACS (2015). Manual on Accessible Tourism for All - Public-Private Partnerships and Good Practices, UNWTO, Madrid. \{on line $\}$ Available from: http://ethics.unwto.org/en/content/accessible-tourism. Retrieved on $\{2 / 10 / 2015\}$.

\section{الإقامة الميسرة : هل المنتجعات في مصر تقدم الذدمات والتسهيلات المتطلبة للنزلاء

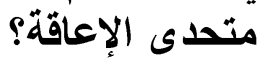

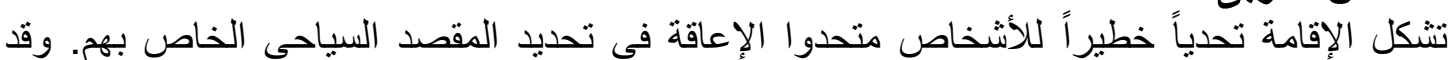

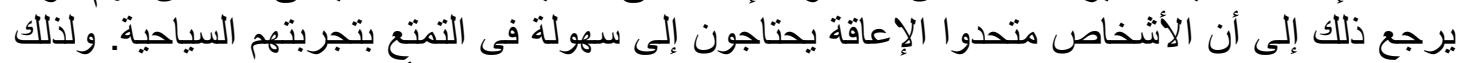

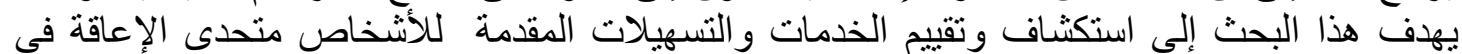

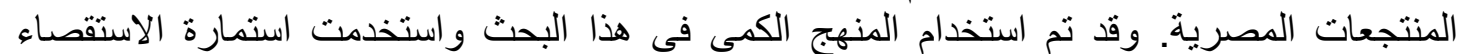

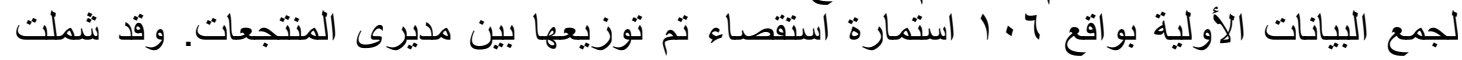

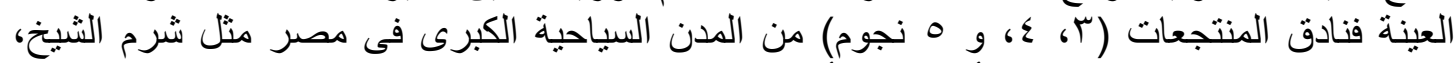

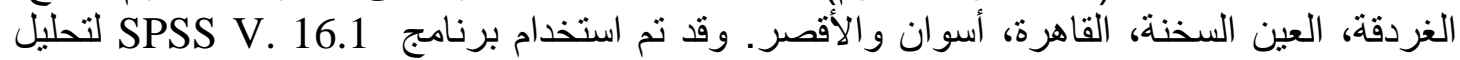

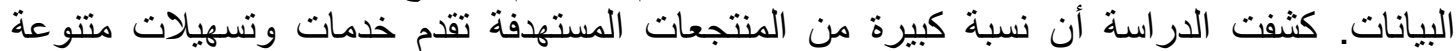

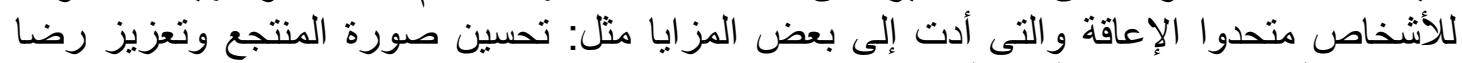

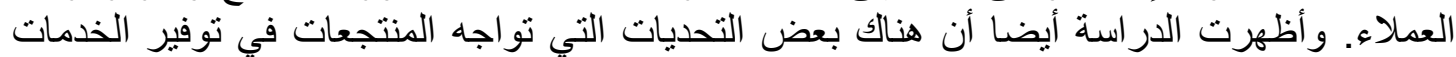

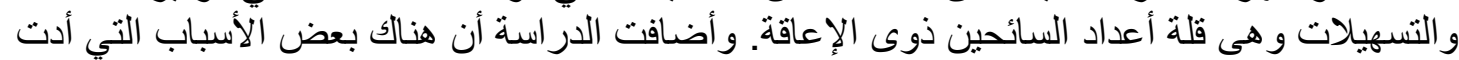

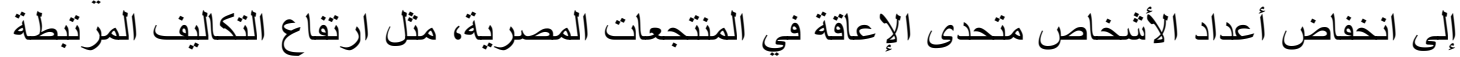
بتوفير المر افق الخاصة بمتحدى الإعاقة. 